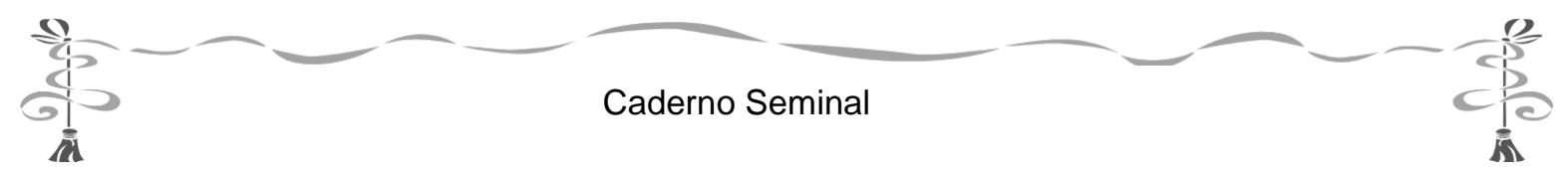

\title{
TECENDO A CULTURA GREGA NO MITO ARACNE: SOB UM OLHAR SEMIÓTICO
}

\author{
WEAVING A GREEK CULTURE IN MYTH ARACHNE: UNDER A SEMIOTIC VISION
}

Claudio Artur O. Rei ${ }^{83}$ \& Marta dos Santos Lima ${ }^{84}$

\section{Resumo}

Este artigo desenvolve uma análise estilística no poema "A aranha", de Manuel Bandeira, com os objetivos de: mostrar a influência da cultura grega na produção literária ocidental, no que tange não só ao aspecto lírico, mas também filosófico; produzir um quadro estilístico-semântico com marcações semióticas que orientam a interpretação das escolhas lexicais que caracterizam o poema eleito para análise; e mostrar a importância da inter-relação entre mito e sociedade, aliados ao valor semântico das palavras, selecionadas conforme o eixo paradigmático, e combinadas, segundo o eixo sintagmático, para dar nova significação às palavras, as quais se concretizam em ambiguidade, a seu turno, fonte de plurissignificação. Os pressupostos das diferentes teorias estilísticas com um apoio subliminar da Semiótica de Peirce e da Teoria da Iconicidade Verbal, de Darcilia Simões servem de moldura para nossa leitura, demonstrando-lhes o potencial indicial, simbólico e semântico.

PALAVRAS-CHAVE: Estilística, Manuel Bandeira, Semiótica, Teoria da Iconicidade Verbal.

\section{Abstract}

This article develops a stylistic analysis on the poem "A Aranha" by Manuel Bandeira, with the following objectives: to show the influence of Greek culture in the Western literary production, in terms handed to the lyrical aspect, but also philosophical; produce a stylistic framework with semiotic-semantic markup that guide the interpretation of lexical choices that characterize the poem chosen for analysis, and show the importance of the interrelationship between myth and society, coupled with the semantic value of words, selected as the paradigmatic axis, and combined according the syntagmatic axis, to give new meaning to the words, which are realized in ambiguity, in turn, source multi signification. The assumptions of different theories with a stylistic subliminal support of Peirce's Semiotics Theory and of Simões's Verbal Iconicity Theory serve to frame our reading, showing them the indexical, symbolic and semantic potential.

Keywords: Stylistics, Manuel Bandeira, Semiotics, Verbal Iconicity Theory.

\section{Palavras iniciais}

Este trabalho é fruto de uma discussão, em sala de aula, acerca do clássico anacoluto existente no poema "A aranha", de Manuel Bandeira, e as implicações estilísticosemânticas que esse recurso retórico fomenta no poeta como um todo. Nesse sentido, pretendemos, por meio de uma análise semiótica, com base nos estudos apresentados por Darcilia Simões, em sua Teoria da Iconicidade Verbal, sob um viés estilístico, perpassando pela filosofia, com o objetivo de uma competência

\footnotetext{
${ }^{83}$ UNESA/SELEPROT - arturrei@uol.com.br

${ }^{84}$ UNESA - profmartalima@hotmail.com
}

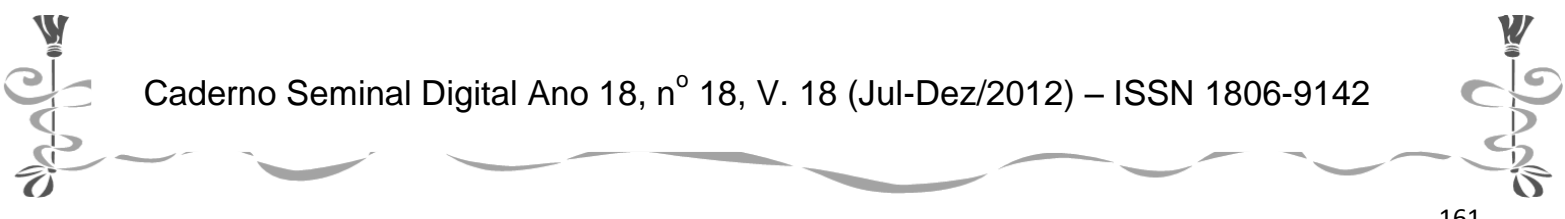




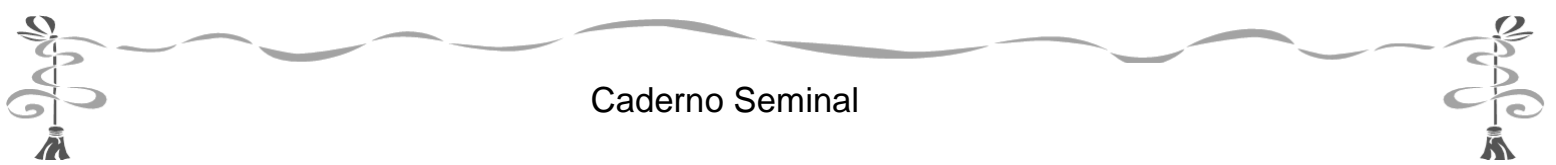

pragmática, discorrer acerca do mito Aracne e seu significado representativo cultural. Para tanto, optamos por utilizar o poema "A Aranha", retomando, assim, o mito Aracne, na busca intencional do conceptus nele inscrito, o que procuraremos demonstrar não só com subsídios enciclopédicos, como também com uma análise linguístico-literária.

O nosso intuito, no entanto, longe de ser a contestação da importância do legado greco-romano para a nossa cultura é uma constatação dessa significância que permeou séculos, tornando-se intrínseco em nossa sociedade. Em acordo com o que nos diz Darcilia Simões (2009, p.27-28):

\begin{abstract}
A semiotização dos objetos culturais se mostra como condição para o entendimento das interações sociais e para o aperfeiçoamento das relações humanas. Quando se fala de descrição e de interpretação do mundo e da realidade, impõe-se pensar em processos sígnicos por meio dos quais são construídos os cenários e as práticas sociais;
\end{abstract}

pelo que nos atreveremos a desvendar por processos significativos, que envolvem um olhar mais apurado sobre a Língua Portuguesa, as nuances de nossa própria cultura, transportadas da cultura grega.

Queremos, assim, ressaltar a importância de uma análise estilístico-semiótica como mecanismo de pesquisa, para a compreensão mais abrangente do que, no ensino da língua, podemos alcançar em relação à percepção do contexto no texto, em uma releitura crítico-analítica.

Com um olhar que visa a acrescer, enriquecendo-nos em conhecimento, pretendemos apresentar a existência do conceito mencionado, sem, no entanto, nos apossarmos de qualquer outra intenção, senão a de novas leituras que nos levem à compreensão das ações humanas, cuja observação foi amplamente levantada pelos gregos e até hoje é objeto de estudo e pesquisa, uma vez que a cultural ocidental tem seu berço na filosofia clássica.

\title{
A Importância da Mitologia.
}

A imagem é uma criação pura do espírito. Ela não pode nascer da comparação, mas da aproximação de duas realidades mais ou menos remotas. Quanto mais longínquas e justas forem as afinidades de duas realidades próximas, tanto mais forte será a imagem mais poder emotivo e realidade poética ela

possuirá... (BRETON, 1985, p. 52)

Discorreremos, a princípio, para um maior alcance do que nos propusemos expor por meio deste artigo e com o objetivo de elucidar os motivos que nos levaram a tal

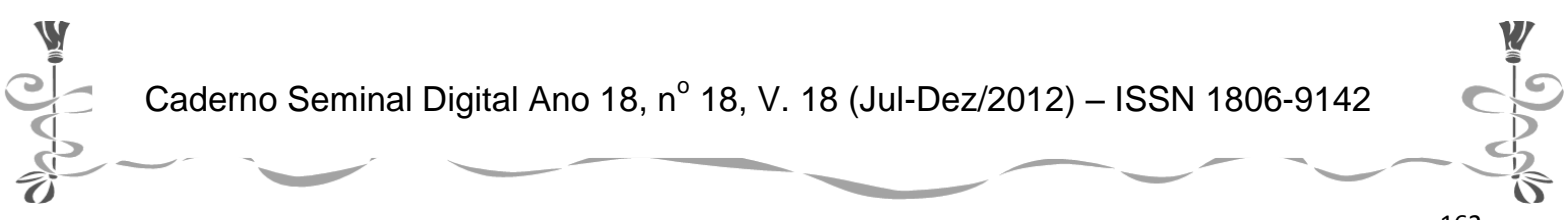




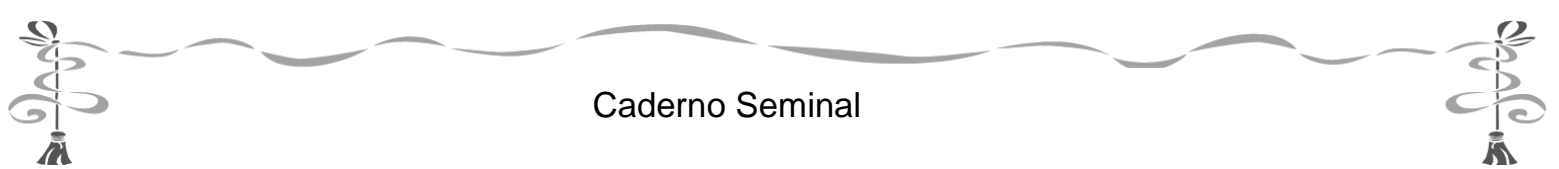

abordagem, acerca da cultura grega e sua importância como influência indiscutível na cultura ocidental, trazendo, assim, assertivas sobre a utilidade dos mitos entremeados de uma consciência coletiva e identidade cultural.

Sob um olhar desavisado, surgem questionamentos, por carregarem certa carga de afetividade, rompendo com o racionalismo, para ascender em subjetividade, todavia, requer-se do mito uma análise mais profunda, a priori, ressarcindo-nos de um menosprezo à sua importância, por seu destaque ao longo da história, na tarefa indiscutível de formação de uma consciência coletiva. Como nos aponta Brandão (1989, p.10): Os mitos são, os depositários de símbolos tradicionais no funcionamento do Self cultural, cujo principal produto é a formação e a manutenção da identidade de um povo.

Seguindo, então, essa esteira de raciocínio, abordaremos alguns pontos encontrados sobre Mitologia Greco-romana, para posterior retomada de um signo cujo significado, explorado com maestria por Manuel Bandeira, vem mostrar a influência desse conhecimento em nossa própria cultura.

É indiscutível que a mitologia faz parte da nossa Literatura Ocidental, pois trazemos, em nossas formas de expressão, assim como na arte e na estrutura do nosso pensamento, toda a sua influência, sendo demonstrada, no nosso cotidiano, de formas variadas, tão enraizada está no nosso "eu". Inferimos, ainda, que, no caso do Brasil, as mitologias são múltiplas, devido à formação de nosso povo, que incluem tradições e superstições indígenas e africanas. Assim, o valor das mitologias se reveste nas diversas manifestações artísticas, sendo abordagens da Psicanálise, da Sociologia, da Filosofia e sempre um ponto de referência para entendimento do pensar e agir humano. Asseveremo-nos ao que diz Ruth Guimarães:

(...) a forma primordial das manifestações do espírito é o mito.(...) Se o mito está na origem da poesia, está, por isso mesmo, na origem da literatura. E, sendo a primeira manifestação da inteligência, é necessário que a conheçamos bem, para entendermos o que vem depois, mais alto e mais abstrato.

Mito pode ser descrito, semioticamente, como indice (pela similitude entre significante e significado), pois a palavra, a imagem, o gesto, que nascem no inconsciente, transformam-se em narrativa, logo, tornando-se icone (pela contiguidade vivida entre significante e significado), modificando-se, então, para a consciência. A sua força se dá devido à busca de uma organização social em benefício do coletivo. É o homem em busca de explicações que o satisfaçam, compartilhando a sua visão de mundo, da realidade, do outro, do indivíduo e do coletivo, o que vem a tornar o mito um símbolo (pela contiguidade instituída entre significante e significado).

Aqui, como Édipo, buscaremos uma decifração para mito, visando a um alcance maior de nossa análise dedutiva, ao nos calçar com a definição de Bronislav Malinowski: (...) uma narrativa que faz reviver uma realidade primeva, que satisfaz a

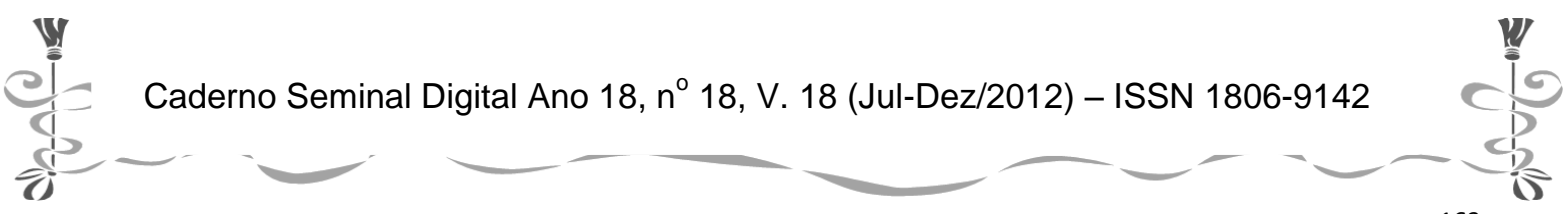




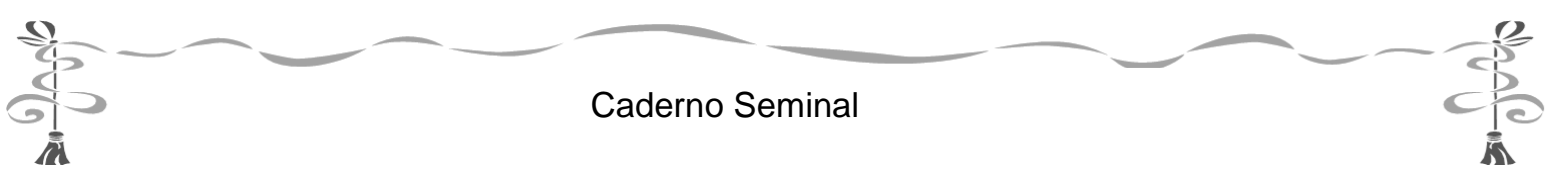

profundas necessidades religiosas, aspirações morais, a pressões e a imperativos de ordem social e mesmo a exigências práticas.

Assim, por agora, nos deteremos na tessitura do já referido poema de Manuel Bandeira que, embasado no mito Aracne, provoca uma releitura da realidade; estabelecendo uma lógica semiótica em que a segunda pressupõe a primeira e a terceira pressupõe a segunda. Analisaremos no poema "A Aranha", sob um viés estilístico-semiótico, buscando, nas escolhas feitas, a intencionalidade do autor: uma retomada do mito "Aracne", presente na cultura grega, e suas implicações sociais, para que, seguindo o rastro da aranha de Manuel Bandeira, chegarmos à percepção de uma lógica cujo significado teceu uma cultura e ligou-nos a um conceito, como nos aponta Simões (2009, p.19): O estudo dos signos linguísticos e seus condicionamentos permite aos linguistas analisar a semiose no plano verbal e com isto projetar suas investigações em planos mais largos como o da Semiótica das Culturas.

\section{Aracne e Manuel Bandeira.}

Para tanto é necessário reconhecer na trama da Aranha o destino de Aracne, por isso optamos por apresentar-lhes o mito e logo após o poema.

Aracne era uma jovem Lídia, filha de Ídmon, tintureiro de Cólofon. Bordava e tecia com tal perícia que até as Ninfas do Tmolo e do Pactolo abandonavam as águas e os bosques para lhe admirar os trabalhos. Sua reputação crescia e era já conhecida pela beleza dos seus tecidos de encantadores desenhos em toda a Grécia. No entanto, entre os seus dotes não se contavam a modéstia. Envaidecia-se de quanto fazia e falava alto e em bom som que não tinha receio de desafiar a própria

Atena, protetora e padroeira dos fiadeiros. A deusa soube. Assumiu o aspecto de uma anciã de cabelos brancos e procurou a moça, aconselhando-a a ser mais comedida, pois que os deuses facilmente se ofendem e a sua gabolice podia resultar em algum mal.
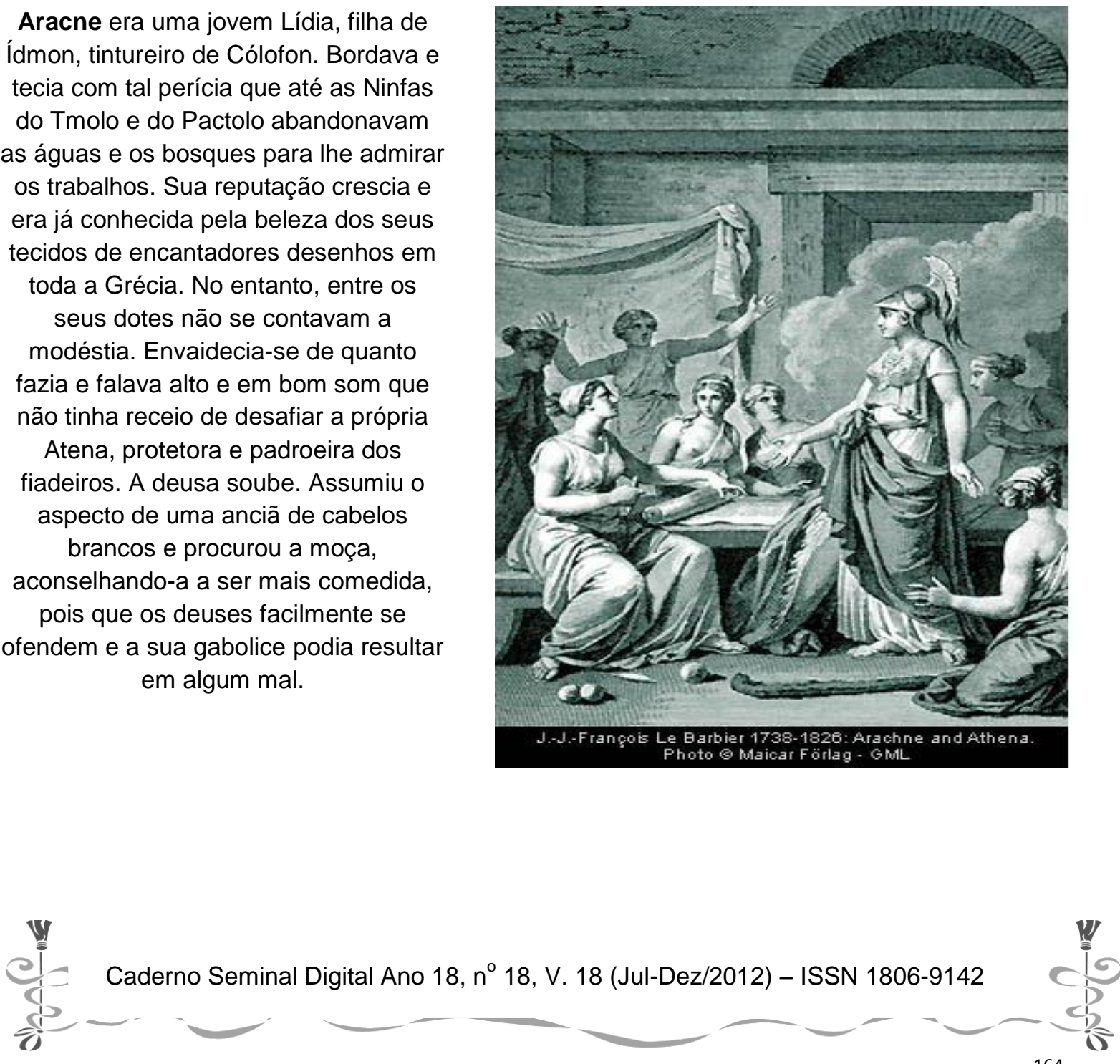


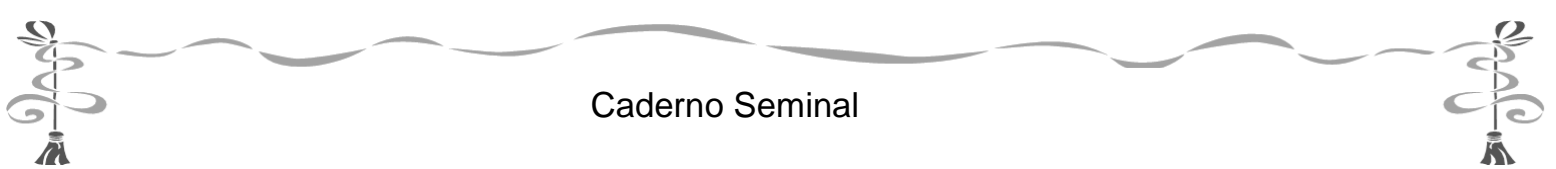

\section{Resumo do mito}

A moça insultou a anciã, e disse que a deusa não apareceria, em resposta ao seu desafio, porque sabia que perderia. Indignada, Atena se revelou em toda a sua imponência de deusa e declarou aceitar o desafio. Dispuseram-se as linhas e começaram a bordar e a tecer. Cada uma delas desenhou histórias. Atenas fixou em lindos coloridos a sua disputa com Poseidon, em torno do nome que deveria ser usado pela cidade de Atenas. Aracne pôs-se a desenhar histórias maliciosas a respeito dos deuses. Desenhou-lhes as metamorfoses, as intrigas, os descarados amores; era um trabalho de sutil maledicência e reprovação. Terminados os trabalhos, a deusa examinou detidamente o trabalho da moça Lídia. Estava uma perfeição. Não lhe achou a menor irregularidade, nem desarmonia de tons, era tudo um capricho, uma delicadeza, uma beleza. Vendo-se, senão vencida, ao menos igualada por um simples mortal, Atena rasgou o delicado trabalho, e ainda por cima feriu a rival com a agulha. Aracne, insultada enforcou-se. Atena sustentou-a no ar e não lhe permitiu morrer. Transformou-a em aranha, e disse-lhe que se queria tecer que tecesse. Seria o seu castigo e de toda a sua descendência. Aracne tinha um irmão, Falaxia, que fabricava armas. (p. 65) ${ }^{85}$

\section{A ARANHA \\ (Manuel Bandeira)}

Não te afastes de mim, temendo a minha sanha

E o meu veneno... Escuta a minha triste história:

Aracne foi meu nome e na trama ilusória

Das rendas florescia a minha graça estranha,

Um dia desafiei Minerva. De tamanha

Ousadia hoje espio a incomparável glória..

Venci a deusa. Então ficou ciumenta da vitória,

Ela não ma perdoou: vingou-se e fez-me aranha!

Eu que era branca e linda, eis-me medonha e escura.

Inspiro horror... Ó tu que espias a urdidura

Da minha teia, atenta ao que meu palpo fia:

10

Pensa que fui mulher e tive dedos ágeis,

Sob os quais incessante e vária a fantasia

Criava a pala sutil para os teus ombros frágeis...

[grifos nossos]

${ }^{85}$ GUIMARÃES, Ruth. Dicionário da Mitologia Grega. São Paulo: Cultrix, 1986.

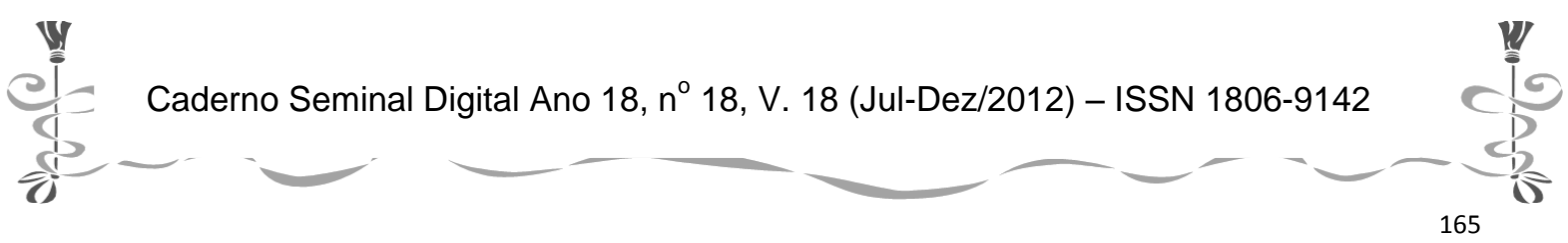




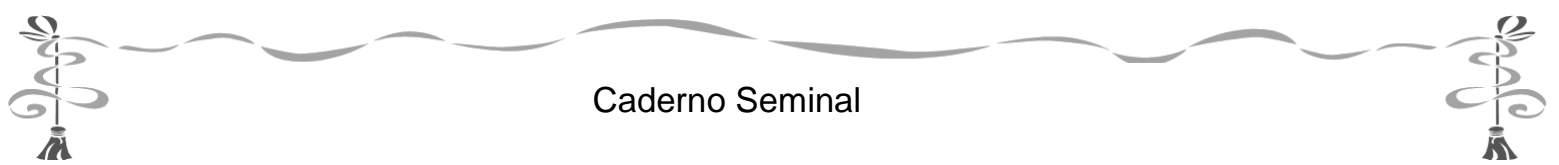

Traçaremos, a partir de uma leitura semiótica, um caminho estilístico que nos proporcione uma compreensão mais abrangente. A semiótica possibilita uma análise tridimensional do objeto, num vislumbre do que está no signo, por trás do signo e além do signo. E, assim, em busca de uma imagem que reflete conceitos, esbarramos, a princípio, na ciência da Aranha cantada por Caetano Veloso - Deu meia-noite, a lua faz o claro / Eu assubo nos aro, vou brincar no vento leste / $A$ aranha tece puxando o fio da teia / A ciência da abeia, da aranba e a minha / Muita gente desconbece ("Na asa do vento") ou Deixe de manha, deixe de manha, pois / Sem essa aranha, sem essa aranha / Sem essa aranha / Nem a sanha arranha o carro / Nem o sarro arranba a Espanha ("Qualquer coisa"). Tecer seria, então, nessa perspectiva, mais que um conhecimento, que uma ciência, seria uma arte que lhe fora dada pela força intuitiva da natureza, como o talento de Lídia que deveria ser agradecida aos deuses por ser considerada exímia tecelã.

No entanto, é importante observar que a tessitura da aranha precisa sempre ser refeita, embora pareça construir sua "casa", na verdade constrói uma armadilha e armazém. Seu tecer traz, como objetivo, ludibriar o seu "futuro alimento" e com suas fiadeiras produz um invólucro no qual sua presa é guardada para ser digerida posteriormente. Nas mitologias antigas, a sua teia, cinco vezes mais forte que o próprio aço e capaz de esticar-se quatro vezes o seu comprimento sem que os seus fios arrebentem, é associada ao cosmos e a aranha é vista como criadora do mundo, responsável em algumas culturas por tecer a realidade, sendo, porém vista em outras como tecedora da aparência ilusória dessa mesma realidade. No ato de tecer a realidade, a aranha é também a que faz o destino do homem ${ }^{86}$.

Manuel Bandeira, utilizando-se dessa imagética, traduz um pensamento, produzindo um forte apelo visual, auxiliando, assim, na construção do entendimento maior de um mundo plural cujas diferenças são descartadas, ao aproximarmos épocas, e, sob um olhar minucioso, averiguarmos os resquícios de um consenso. Como defende Gaston Bachelard ao conceituar a imaginação: não é, como sugere a etimologia, a faculdade de formar imagens da realidade, é a faculdade de formar imagens que ultrapassam a realidade, que cantam a realidade (2005, p. 18).

O autor do poema revive, em versos, valores estéticos da Antiguidade Clássica, seguindo, assim, a estrutura do parnasianismo com preciosismo rítmico e vocabular e ampla descrição visual, trazendo-nos efeitos pela sonoridade das palavras e dos versos, além de certa melancolia e um sentimento de angústia vivido por Aracne. "A Aranha" se constrói em dois quartetos e dois tercetos, seguindo uma estrutura fixa, primando, assim, por uma recuperação desse valor estético clássico.

\footnotetext{
${ }^{86}$ Em "A moça tecelã", de Marina Colasanti, fica-nos bastante nítida essa visão tecer e destecer o destino dos homens.
}

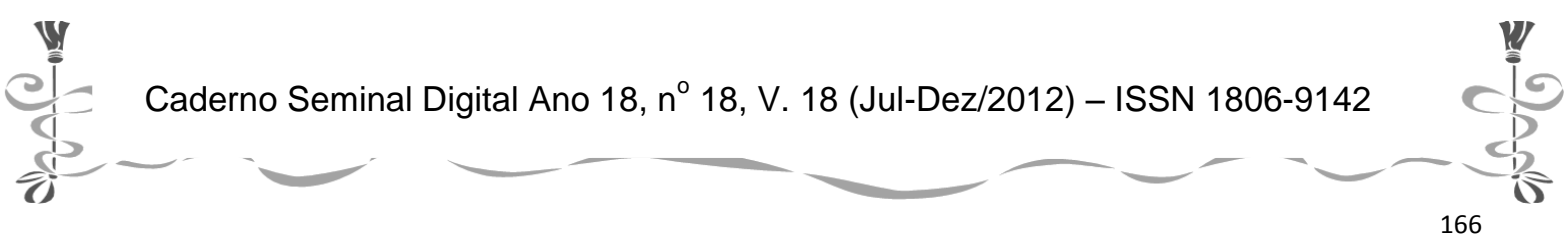




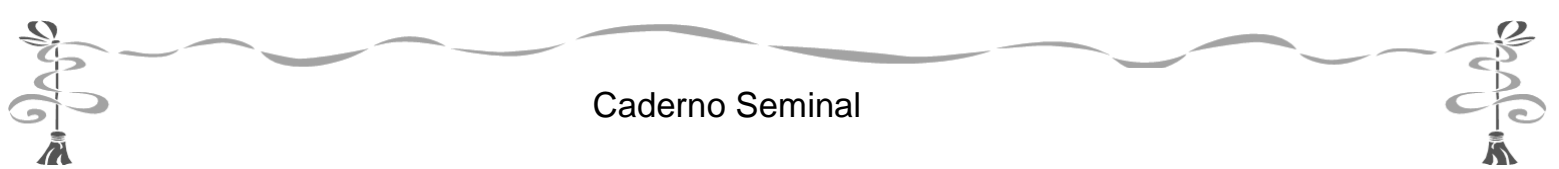

O eu-lírico pronuncia-se com um apelo dramático chamando o leitor para uma realidade que retorna no tempo, alcançando, assim, a historicidade greco-romana, buscando com isso a catarse, uma participação efetiva por parte do leitor/ouvinte que podemos observar no pedido (...) Não te afastes de mim (...) Escuta a minha triste história. Ocorre a fusão entre o sujeito e o objeto, tornando-se perceptível a essência do ser tematizado: Aracne foi men nome (...) Eu que era...

Destacamos, ainda nesse poema, em um processo de seleção de palavras utilizadas - Da minha teia (...) na trama ilusória —, componentes de imagens míticas, percebendo a linguagem mítica com expressivo poder de representação da experiência humano-existencial, pelo que, no tecer da trama ilusória, encontra-se um "sobrecódigo" imposto pela primeira. Para Jung, o mito tornava-se uma estrutura simbólica ao materializar o inconsciente coletivo (Brandão, 1989, p. 37).

As palavras teia \& trama, ambas com significados que apontam para um conjunto de fios: teia, fios produzidos pela aranha e trama fios utilizados pela tecelã, enquanto trama pode também significar enredo, intriga apontando para mito, passam a funcionar como ícones-símbolos na trama sígnica. Assim, o autor, em sua seleção e combinação lexicais, explora as diversas opções, para melhor estabelecer a desejada intenção literária, repassando a impressão intencional e partindo das escolhas lexicais para a produção do texto, a princípio, criando o universo da aranha, levando em conta o contexto, junto aos elementos de situação e interação, o que torna possível a obtenção de uma interpretação mais equilibrada e que nos leva ao enredo proposto no qual a tecelã, em um ato de desafio aos deuses - De tamanha ousadia , vence a deusa, tornando-se alvo de um castigo.

Dentro da mitologia grega, percebemos os deuses como tecelões sobre o destino dos homens, intervindo e modificando de acordo com os seus caprichos, como em a Odisseia, um poema épico da Grécia antiga, do Século VIII a.C. no qual Ulisses vagueia dezessete anos, por ter desafiado Poseidon, e fica à mercê de Calipso, em sua ilha, só voltando para Ítaca, quando os deuses assim decidem. Diante de tal assertiva, voltamo-nos para a intencionalidade contida na composição do texto, pelas escolhas feitas, reconfigurando e remodelando, a partir de um olhar em busca de signos preferenciais.

Aproveitando essa linha de pensamento, gostaríamos de fazer um parêntesis sobre a questão de Ulisses que serve como interseção tanto para a ideia da vontade dos deuses sobre os homens quanto para a tessitura. Penélope, mulher de Ulisses, herói do poema Odisseia, viveu a ausência de seu marido por vinte anos, período em que ela se porta com dignidade e absoluta fidelidade; mas, por um lado, sua formosura, e, por outro, os bens familiares atraem a cobiça de pretendentes, a quem convinha julgar morto seu marido. Ela lhes dizia que só escolheria o futuro marido, após tecer uma mortalha, que, a bem da verdade, não fazia questão de terminar: passava o dia tecendo e, à noite, às escondidas, desmanchava o trabalho realizado. E, enquanto seu marido se mantinha ausente, embora por tanto tempo sem notícia, ela se vestia

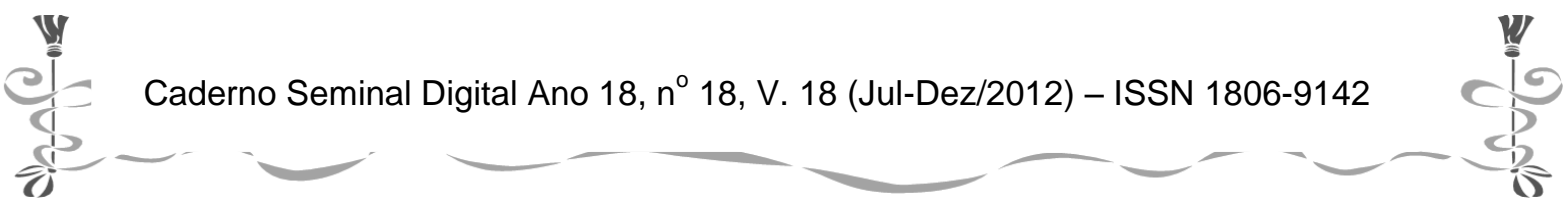




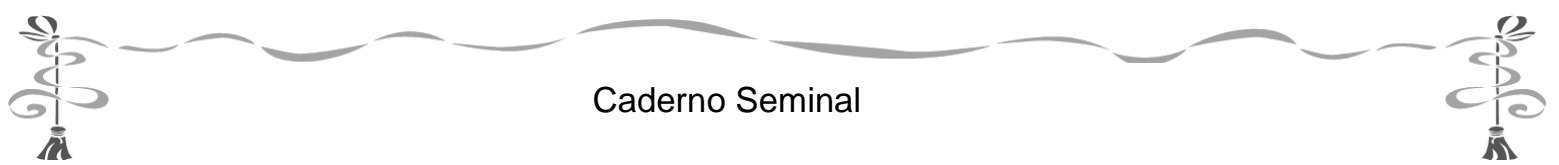

de longo, tecia longos bordados, ajoelhava-se, pedia e implorava para a deusa Atena que providenciasse o retorno de seu amado.

No entanto, é importante notar a forma subentendida com que o autor se refere à Penélope no poema. Segundo a história de Penélope, na Odisseia, a virtuosa esposa de Ulisses convence seus pretendentes de que deveria fazer uma túnica, que serviria de mortalha para cobrir o corpo de Laertes, o venerável pai de Ulisses, que, com a notícia do casamento de sua nora, morreria de depressão, dado ao avançado da idade. E como era costume as mulheres tecerem uma mortalha para os entes queridos que se encontravam prestes a deixar este mundo, Penélope usa desse artifício para ganhar tempo ante seus pretendentes, que aquiesceram de pronto, por ser uma proposta justa. Entretanto, ela nunca a terminaria, pois sua intenção era a de fazer com que seus pretendentes desistissem da ideia de disputar o lugar de Ulisses, devido à demora na confecção da mortalha. Então, a esposa do aventureiro Ulisses é conhecida, na mitologia grega, como o símbolo da mulher que tece longos bordados, enquanto seus maridos se ausentam por períodos delongados.

Ainda em relação ao mito de Penélope, gostaríamos de apresentar um apontamento de Cafezeiro (1999: 123), quando diz: Penélope tece uma mortalha que significa o seu desespero entre a esperança e a morte, mas, no texto e no tecido, se incluem estratégia e astúcia. Ela tece e destece para alongar o tempo e o espaço do texto. Não seria, então, essa possibilidade de "tecer \& destecer" o texto que levou Manuel Bandeira a criar o anacoluto em seu poema, mostrando que a transformação de Aracne foi uma "confecção" dela própria, efeito de sua arrogância?

Inferimos essa possibilidade, uma vez que o poema transmite claramente a ideia de ciúme, vingança e castigo imposto pelo desafio, em paradoxo com a graça concedida e homenagens cedidas à moça pelo seu talento, no último verso do primeiro quarteto (...) das rendas florescia a minha graça estranha, pois, segundo o mito, não havia outra tecelã com tal habilidade. Seria, portanto, o castigo uma consequência da soberba da jovem, causada pela ousadia demonstrada no "desrespeito aos deuses", controladores do destino do homem.

No verso nono, o poeta valendo-se do já comentado anacoluto, refere-se à metamorfose sofrida pela tecelã, dando ao texto a necessária imagem de surpresa e transtorno, com uma construção que provoca na mente do leitor um repelão, percebemos dessa forma o anacoluto não como uma ruptura de linearidade sintática, mas como uma ruptura da fisionomia: Eu que era branca e linda, eis-me medonha e escura. Utilizando-se desse recurso estilístico, consegue, assim, retratar com maior clareza o cunho de retaliação àquela que era visitada pelas Ninfas, seres mitológicos de beleza extraordinária, que, segundo o mito, vinham admirar o seu trabalho. Seguiria, então, a partir desse momento, afastada, em sua condição de aracnídeo, da sociedade e perderia a admiração desses seres por seu desagravo. Podemos destacar, também, nesse mesmo verso palavras que poderiam ser consideradas antíteses: branca \& escura, linda \& medonha, pela ideia visual que transmitem, ressaltando a idealização do

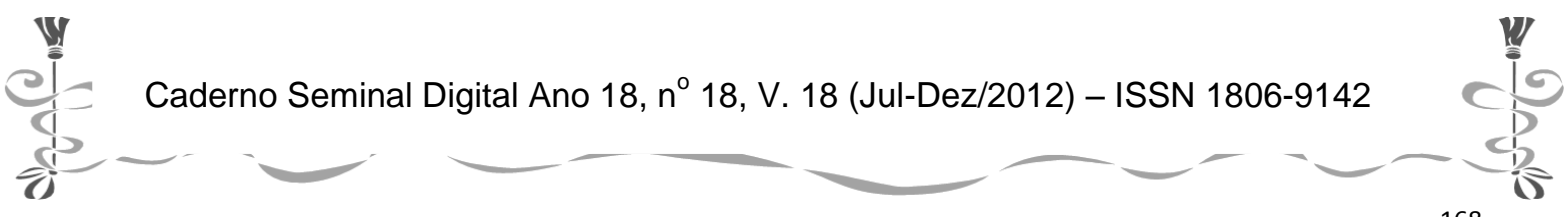




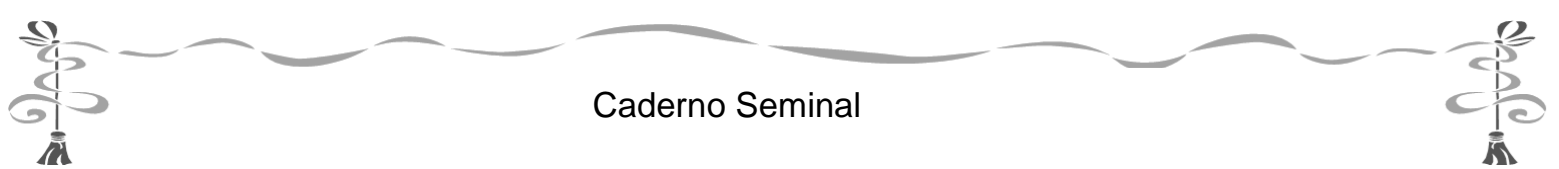

belo dentro da cultura greco-romana, na descrição da jovem, e a representação do horror causado pela transformação. A aracnofobia como uma resposta instintiva ou mesmo um fenômeno cultural. Devido à força léxica empregada, para retratar a metamorfose, a aranha deixa de ser uma imagem metafórica e surge coexistindo com a mulher. Vale destacar o valor expressivo do pronome átono me presente nesse anacoluto, conferindo ao sujeito do discurso a característica de objeto das ações praticadas pela Deusa. Sousa da Silveira faz um belíssimo comentário estilístico desse uso pronominal no poema em questão. Resumindo primeiramente o episódio mitológico retomado por Bandeira, Sousa da Silveira (1983: 272) diz:

Tendo vencido a Minerva numa competição, a exímia tecedeira Aracne foi transformada pela vingativa deusa em Aranha. [...] A oposição entre os adjetivos branca e escura, linda e medonha, faz ressaltar a perversidade da vingança; o anacoluto "eu... eis-me", com a mudança abrupta da construção, pinta a mudança operada pela metamorfose. As formas pronominais eu, sujeito, e me, objeto, salientam os dois estados, avivando o seu contraste: eu, sujeito, a atividade, a satisfação de ser bela e hábil; me, objeto, o resultado da ação cruel mostrado na vítima, no objeto dela: "eis-me medonha e escura".

É importante notar que as construções paratáticas encontradas no poema, na quebra de um raciocínio lógico, voltam-se para a transmissão de estados emocionais, o que possibilita ao leitor/ouvinte, uma carga emocional pelo fato de tornar a linguagem mais expressiva.

Utilizando-se de palavras pertencentes ao mesmo campo semântico; teia, trama, urdidura em escolhas que refletem o pensamento do eu-lírico, o poema repassa o mito sob uma visão diferenciada, com um critério de escolhas, orientado para a manifestação psíquica e para o apelo em que o drama é exposto de acordo com a perspectiva da aranha que descreve toda a carga do ato sofrido por ela. Há uma relação entre os significados e as semelhanças implícitas, além de uma forte tonalidade afetiva, marcas características do estilo do autor.

Podemos ainda observar, no poema, a utilização de verbos que induzem a um "presente psicológico" tais como Escuta. Eis-me. Inspiro. Pensa, retirando do texto o sentido anacrônico e dando-lhe um maior dinamismo, ligando o passado ao presente, assim como o mito está ligado à nossa cultura. O tempo cronológico, perceptível por meio dos verbos e das construções frasais é um recurso estilístico utilizado pelo autor, dando-nos com isso a impressão de vivenciar o fato (...) o tempo cronológico resulta das mudanças, que se operam constantemente no mundo físico e no mundo interior de cada um, mudanças essas de que tomamos consciência, colocando-as numa sucessão (MELO, 1976: 158).

Observamos que, na terceira estrofe, o eu-lírico (Aracne) faz menção à urdidura de sua teia, como se, naquele exato momento, estivesse tramando, fiando um enredo que recairia sobre os nossos ombros e, por meio da construção de uma pala sutil,

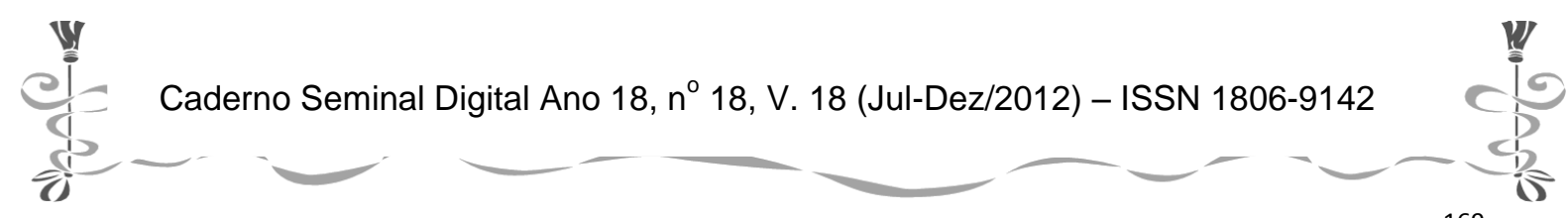




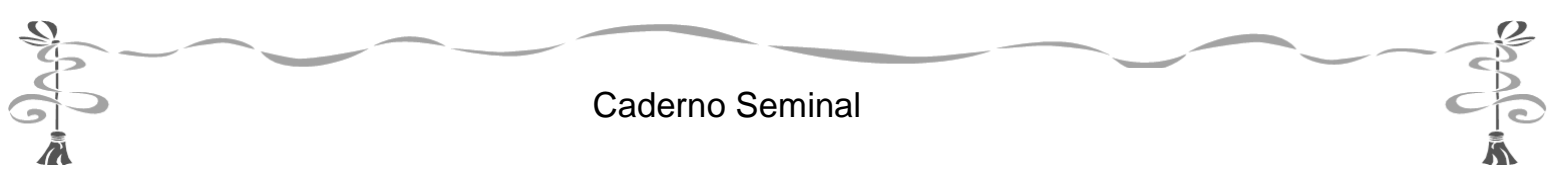

revela a fragilidade humana, ligando-nos, assim, a um contexto que nos leva a certas indagações: o que o mito aponta? Sob que bases se afirma? Que conceito se entremeia em sua tessitura? De acordo com a análise feita, no intuito de como interpretá-la, assimilar e decodificar os signos implícitos, percebemos que as relações indiciais dos signos linguísticos nos levam a vê-los com valores icônicos tão abrangentes que se tornam símbolos, pois começamos a observar o que está além do mito e que de maneira metafórica adentrou na cultura ocidental, sob aspecto de religiosidade, sendo parte da nossa identidade cultural em resposta à fragilidade humana, mencionada por Manuel Bandeira. Diante de tais assertivas, asseguramonos de que, de acordo com o que nos atesta Simões (2009, p. 83):

A produção imagética se desenrola conforme o projeto de raciocínio. Pode ser dedutiva ou indutiva.

Esta vai reunindo um a um os signos de que se constitui o texto de modo a compor o seu significado global; enquanto aquela parte do todo do texto e tenta decompô-lo em partes menores que possam referendar a ideia global que lhe fora atribuída.

Nesse sentido, buscando investigar os significados contidos nos signos utilizados e contribuindo, dessa forma, para uma representação de mundo, optamos pelos efeitos produzidos no poema eleito e, para tal, levamos em conta sempre o contexto, junto aos elementos de situação e interação, lembrando que a pragmática aborda as relações entre os signos e seus usuários desenvolvendo uma "rede de encadeamentos discursivos" (Ducrot, 1998, p.17). Saussure identifica o significado como a imagem mental do conceito, ou seja, a ideia que se forma do objeto representado; já Castelar de Carvalho (1984, p. 41) caracteriza o signo literário e fundamenta: Fazer literatura implica uma seleção estético-vocabular, havendo, portanto, motivo da parte do escritor para preferir tais e tais signos e rejeitar outros.

Discorremos nesse ponto, para maior esclarecimento, no intuito de assim transpor dúvidas que possam surgir acerca do que aqui repassamos, acerca do espaço simbólico que passa a ser identificado como a realidade, nesse caso, apontado como a língua falada, na forma de mito, cuja representação expressa o modo comum de pensar e agir confirmando uma cultura. Como ser socialmente adaptado, o ser humano, em um espaço de convenção, incorpora os valores instituídos pelos objetivos e conveniências da cultura o que se torna a sua realidade.

Partimos, então, do plano de expressão, ou do significante para o conteúdo, numa análise do texto poético em que o ideal da semiose ilimitada pode se realizar mais plenamente em um certo modo de formar e compreender a realidade inerente à obra. Seixas (1987, p. 169) observa:

(...) Enquanto o signo linguístico, por seu compromisso pragmático, atende às necessidades e anseios do espaço de convenção, o signo poético, formalmente aberto, de estrutura remissiva, se presta mais

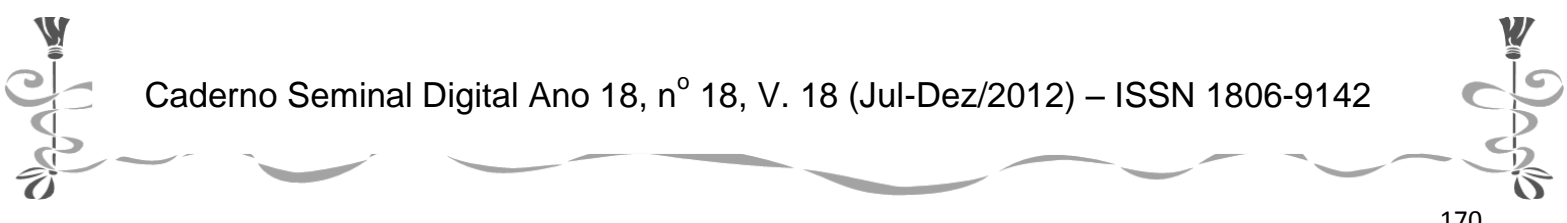




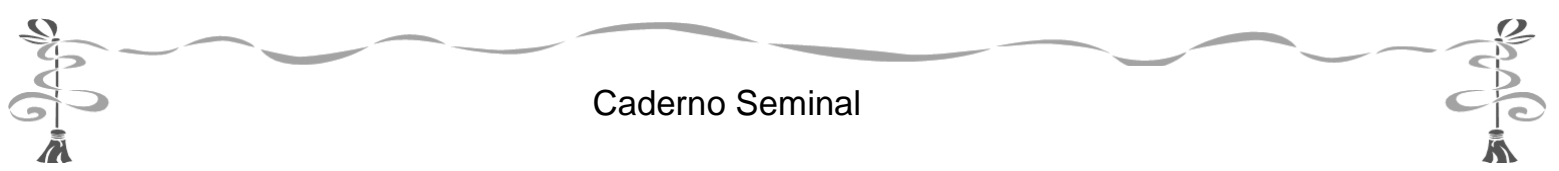

eficientemente a captar e enformar, informando, o não formalizado espaço de transgressão.

Esbarramos dessa maneira na transubstanciação em o que objetos são ideias, são valores, e nos signos encontramos razões e inter-relações que preenchem espaços, lacunas espirituais.

À procura do que está subtendido no texto, e do que está por trás e até mesmo além do mito, na ânsia de eternidade inclusa no espírito humano, como instinto de perpetuação de vida, voltamo-nos para os dias atuais e em "A Aranha" deduzimos a influência que entrelaça a visão religiosa ocidental de relacionamento entre divindade e humano.

O eu-lírico, no verso onze, do poema em destaque, aponta para trás (...) atenta ao que meu palpo fia: trazendo a força da noema como um ensinamento, ou seja, a trama sobrepuja a Paideia. Logo em seguida, há uma retomada do primeiro estado na menção da figura da mulher, o que observamos em sua importância, pois nela vê-se o efeito do mito. A questão ideológica da mulher, como objeto de submissão dentro de uma sociedade, revela-se no fato de serem vistas culpadas de todas as falhas e males humanos, o que as acompanhou durante todo o contexto histórico, apesar de Aracne ser castigada por outra mulher, culturalmente, essa metáfora demonstrava o caráter subserviente a que a mulher estava atrelada, não lhe sendo permitido rebelarse, sob qualquer pretexto. A Política, de Aristóteles, justifica tal comportamento feminino, em virtude de sua não plenitude da parte racional da alma, atestando, assim, a sua incapacidade para um "bom pensamento". Hodiernamente, afirma-se o mito que explicita o pecado original, justificando e conduzindo atitudes e responsabilizando a mulher como a origem de todos os males. Enquanto o mito ressalta na mulher o desagrado dos deuses, Manuel Bandeira, na voz do eu-lírico, enaltece o seu talento, a sua capacidade: e tive dedos ágeis, / Sob os quais incessante e vária a fantasia / Criava a pala sutil para os teus ombros frágeis... enquanto desmascara a construção do próprio mito, que, por meio da fantasia, traz uma mudança que se impõe sobre a fragilidade humana.

Assim, apontamos para a fragilidade mencionada no fim do poema, caracterizando a raça humana, o que nos induz ao conceito de subserviência ao divino com risco de um castigo atroz, caso seja a divindade desafiada, pelo que atestamos, dentro da nossa cultura ocidental, um não questionamento quanto à vontade divina, e uma total entrega do nosso destino, como pressuposto para a nossa própria existência. Essa imagética educativa tornou-se parte do nosso contexto, vigorando em um senso comum que afirma nossa identidade social. Frases como "se Deus quiser", “Tudo é como Deus quer", "Seja como Deus quiser” ou mesmo "Queira Deus!", são indícios comprobatórios que nos servem como constatação do que aqui foi exposto.

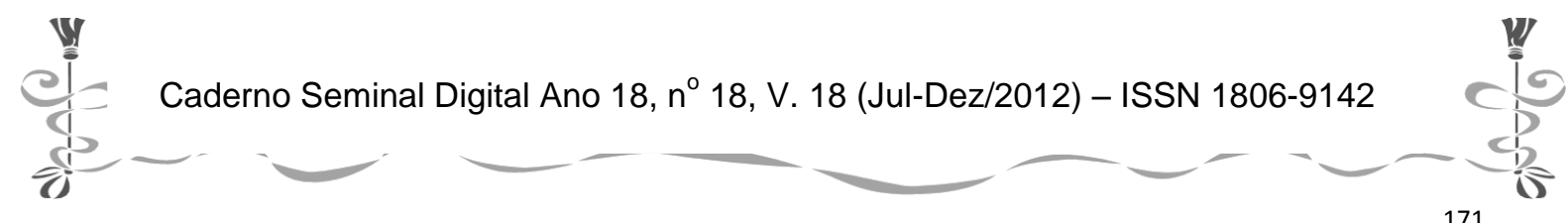




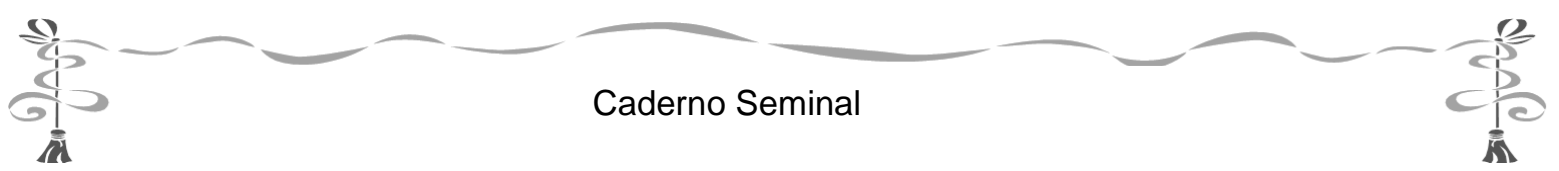

\section{Palavras finais}

Procuramos mostrar, assim, por meio deste artigo, a considerável intervenção da cultura grega na nossa identidade social, o que se tornou possível, mediante os mecanismos utilizados, ou seja, a Estilística como meio de reflexão acerca do que encontramos atrás dos textos em um olhar cuidadoso, utilizando recursos com vezo estilístico e a semiose, sob o olhar de Darcilia Simões, em sua Teoria da Iconicidade $V e r b a l$, que nos levou para além do texto, em um diálogo cultural.

Sob um olhar semiótico, conseguimos resgatar, no tempo e no espaço, a emblemática cultural que nos rodeia, com o intuito exclusivo de, no respeito ao outro, entendermos o entrelace das culturas, minimizando, assim, as diferenças e amenizando os anseios humanos que nos circundam. Conhecer as origens nos torna iguais e, sendo iguais, embora diferentes como indivíduos, problematizamos menos $\mathrm{e}$, consequentemente, facilitamos as inter-relações sociais.

No ensino da Língua Portuguesa torna-se viável, por meio de leituras textuais, promovermos uma releitura de mundo, concebendo questionamentos racionais .Por meio de um estudo científico, com base na teoria semiótica de Pierce, é possível incorrer em uma análise coerente buscando preencher lacunas e desvendar princípios, valores e situações que estão presentes em nossa sociedade.

Convém enfatizar que essas associações só se tornaram possíveis por apresentarem consistência técnica, porque nossa análise estilística teve um suporte semióticopragmático. Procuramos ler o poema dialogicamente, isto é, consideramos sua leitura num contexto maior: histórico, cultural, ideológico, etc. do qual pudemos extrair a noção de que sentido e sentimentos estão a serviço dos propósitos perseguidos na realização e na compreensão do poema.

O outro aspecto foi o cuidado para não nos perdemos dos caminhos traçados deixando-nos inebriar pela riqueza linguística do texto eleito. Receamos que tal atitude pudesse conduzir a análise para caminhos tortuosos e mais vulneráveis às subjetividades (às vezes bastante perigosas!) como as que nos assaltaram nas inferências, nas relações semióticas, nas incursões históricas e literárias... Enfim, temíamos fugir do objetivo que nos propusemos: o de reconhecer traços estilísticos no poema e, a partir do reconhecimento, fazer uma análise estilística (com fundamentos semióticos e pragmáticos, ainda que sejam subliminares), além de mostrar a influência da cultura grega no pensamento ocidental hodierno. Por isso, não foi fácil controlar a emoção e as pulsões provocadas pela riqueza do poema agravada pelo amor à obra eleita.

\section{Referências:}

BACHELARD, Gaston. O Ar e os Sonhos. 2 ed. São Paulo: Martins Fontes, 2005.

BANDEIRA, Manuel. Estrela da Vida Inteira. Rio de Janeiro: Record/Altaya, 1999.

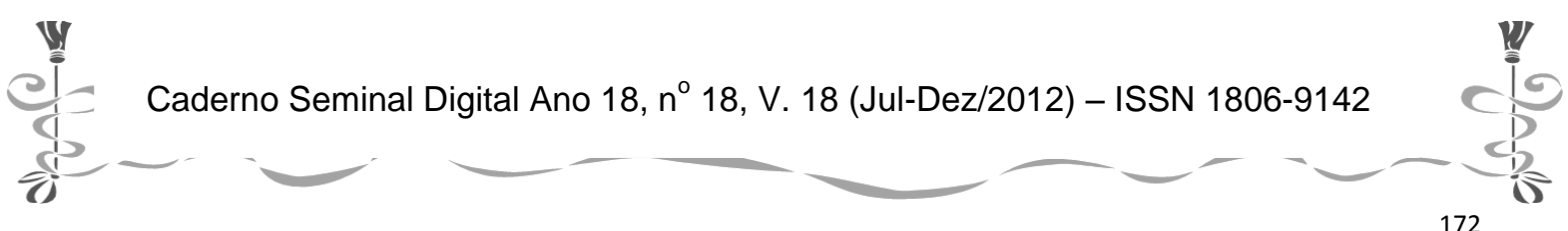




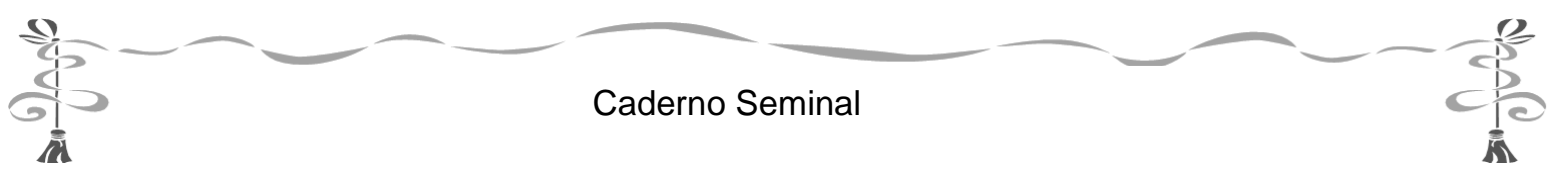

BRANDÃO, Junito de Souza. Mitologia Grega volume I. 5 ed. Petrópolis: Vozes, 1989.

CAFEZEIRO, Edwaldo. "O texto e seus teares". In: VALENTE, André Crim (org.). Aulas de Português — perspectivas inovadoras. Petrópolis: Vozes,1999.

CARVALHO, Castelar. Para Compreender Saussure. $4^{\text {a }}$ ed. rev. e ampl. Rio de Janeiro: Ed. Rio, 1984.

CIVITA, Victor. Dicionário de Mitologia Greco-Romana. 2 ed. São Paulo: Abril Cultural, 1976.

GUIMARÃES, Ruth Dicionário da Mitologia Grega. São Paulo: Cultrix, 1986.

CHAVES DE MELO, Gladstone. Ensaio de Estilística da Lingua Portuguesa. Rio de Janeiro: Padrão, 1976.

SANTAELLA, Lucia. A Teoria Geral dos Signos — semiose e autogeração. São Paulo: Ática, 1995.

SEIXAS, Cid. "O Espaço da Transgressão". In OLIVEIRA, Ana Claudia de \& SANTAELLA, Lúcia. Semiótica da Literatura. São Paulo: Educ, 1987. Série Cadernos - PUC 28

SILVEIRA, Sousa da. Lições de Português. 9 ed. Rio de Janeiro: Presença, 1983 (Coleção Linguagem; $\left.\mathrm{n}^{\circ} 23\right)$.

SIMÕES, Darcilia. Teoria da Iconicidade Verbal Rio de Janeiro: Dialogarts, 2009.

Caderno Seminal Digital Ano 18, nº 18, V. 18 (Jul-Dez/2012) - ISSN 1806-9142

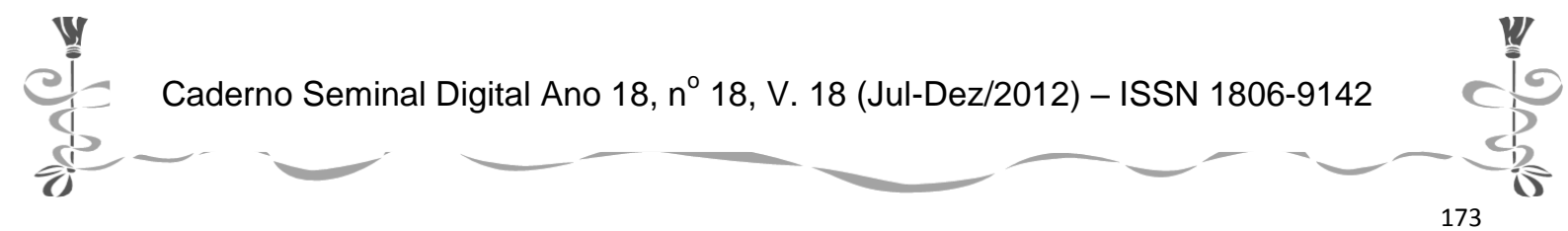

